\title{
Lik antidepressiv effekt av ulike antipsykotika
}

\section{Fire av de mest brukte antipsykotika i Norge har samme antidepressive effekt ved akutt psykose. Det viser en studie fra Bergen.}

Depressive symptomer er vanlig ved psykotiske lidelser og forverrer prognosen. Det er holdepunkter for at noen annengenerasjons

antipsykotika har stemningsstabiliserende egenskaper og at den antidepressive effekten er ulik for ulike preparater.

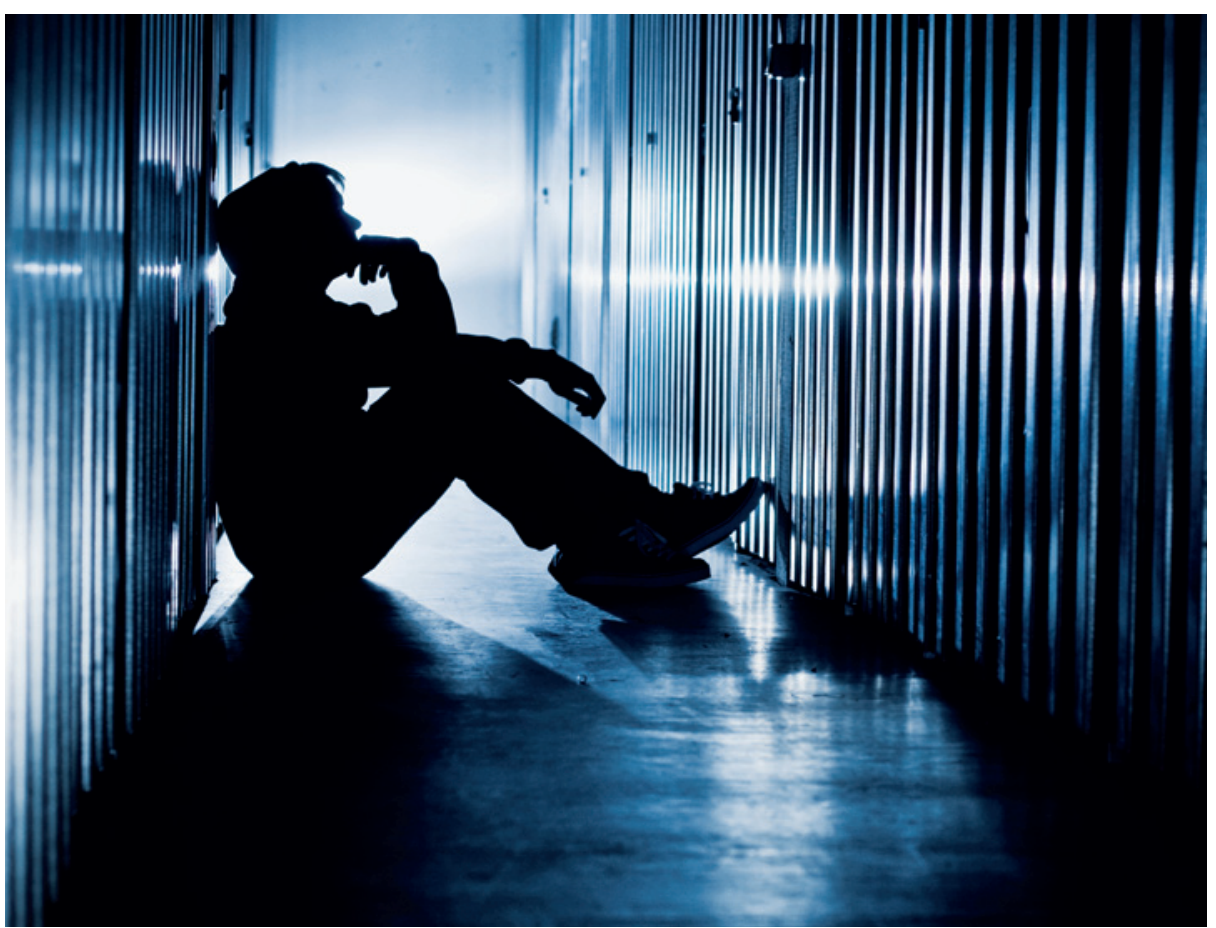

Illustrasjonsfoto Istockphoto
Vi har gjort en studie av 226 pasienter fra den naturalistiske studien Bergen psykoseprosjekt (1). Pasientene, som var innlagt akutt med psykotiske symptomer ved Psykiatrisk akuttmottak, Haukeland universitetssykehus, ble randomisert til olanzapin, quetiapin, risperidon eller ziprasidon og testet regelmessig i opptil to år. Hovedutfallsmålet var forandring i Calgary Depression Scale for Schizophrenia, som er en skala utviklet og validert for måling av depressive symptomer ved schizofreni. Det ble også registrert bruk av stemningsstabiliserende medikasjon, antidepressiver og benzodiazepiner.

Vi fant bedring av depresjonssymptomer $i$ alle grupper, men ingen statistisk signifikante forskjeller mellom gruppene for hovedutfallsmålet eller ved bruk av andre psykofarmaka. Resultatene er i overensstemmelse med andre studier.

Studien viser at det ikke er grunnlag for å anbefale ett antipsykotikum fremfor de andre undersøkte preparatene ved behandling av depresjonssymptomer hos pasienter som er innlagt akutt pga. psykose.

\section{Eirik Kjelby}

eirik.kjelby@helse-bergen.no

Psykiatrisk divisjon

Haukeland universitetssykehus

\section{Litteratur}

1. Kjelby E, Jørgensen HA, Kroken RA et al. Antidepressive effectiveness of olanzapine, quetiapine. risperidone and ziprasidone: a pragmatic, randomized trial. BMC Psychiatry 2011; 11: 145.

\section{Ereksjonssvikt etter behandling for kolorektal kreft}

\section{Mange menn opplever erektil dys- funksjon etter behandling for kolo- rektalkreft. Likevel tar få leger opp temaet med pasientene.}

Mange menn med kolorektalkreft opplever erektil dysfunksjon etter behandling. Dette kan redusere livskvaliteten både hos mannen og hans partner. Det finnes en del studier av ereksjonssvikt etter prostatakreftbehandling, men lite forskning er gjort på dette området for kolorektal kreft. Britiske forskere har nå gjort en kvalitativ studie av menns erfaringer med erektil dysfunksjon etter operasjon for kolorektalkreft (1).

28 menn deltok i et semistrukturert, kvalita- tivt intervju. 24 av deltakerne var operert, hvorav 13 hadde stomi. 20 deltakere var behandlet med kjemoterapi og 13 med radioterapi. 24 hadde erektil dysfunksjon, men det var stor variasjon i erektil funksjonsskår og alder. Mange av mennene var ikke blitt informert om risikoen for ereksjonsproblemer etter behandling.

- Denne studien retter oppmerksomheten mot en lite omtalt langtidseffekt etter kreftbehandling, sier overlege Marianne Guren ved Avdeling for kreftbehandling, Oslo universitetssykehus. - Forekomst av seksuell dysfunksjon har vært undersøkt etter behandling for endetarmskreft i Norge. Den britiske studien viser at blant menn som opplever erektil dysfunksjon etter behandling for kolorektalkreft, er det få som søker hjelp eller behandling for det, sier Guren.
- Studien er basert på kvalitativt intervju, og flere menn oppga at de ikke hadde snakket med legen om sine ereksjonsproblemer. $\AA$ ta opp dette temaet inngår ikke rutinemessig ved oppfølging av pasientene, verken i Storbritannia eller i Norge. Leger bør i større grad være oppmerksom på seneffekter i oppfølgingen etter kreftbehandling, sier Guren.

\section{Trine B. Haugen}

trine.b.haugen@hf.hio.no

Tidsskriftet

\section{Litteratur}

1. Dowswell G, Ismail T, Greenfield S et al. Men's experience of erectile dysfunction after treatment for colorectal cancer: qualitative interview study. BMJ 2011; 343: d5824. 